\title{
Does Size Matter? Economies of Scale in the Credit Union Industry
}

\author{
Su-Jane Chen
}

\begin{abstract}
This study employs a paired difference approach to explore economies of scale in the credit union industry. Tests performed on aggregate credit union data strongly support the existence of scale economies. Empirical results suggest that the larger the credit union size is, the more efficiently it operates in terms of operating costs as a percentage of both total assets and operating income. Moreover, economies of scale evidenced in this research have become more pronounced post 2008 financial crisis, supporting the notion that they change over time. This documented enhancement in scale economies provides the rationale for the industry's proliferating consolidations via merger and acquisition activities.
\end{abstract}

Index Terms-Credit unions, economies of scale, operational efficiency.

\section{INTRODUCTION}

Credit unions are not-for-profit, cooperative organizations owned by members who share a common bond. These member owners borrow funds from and deposit money into their credit unions. This unique owner-consumer nature poses a conflict of interest between existing members and potential new members as a credit union grows. As pointed out by [1] and reiterated by [2], [3], conflicts may arise among members as an increase in demand for loans by new members drives up the borrowing rates while a rush of deposits by new members pushes down the savings rates, both of which are detrimental to the growing credit union's current members. The authors then claim that economies of scale serve as an ideal mechanism to alleviate such potential member conflicts and to conserve the cooperative nature of credit unions. Reference [4] also asserts that credit unions, in hopes of realizing economies of scale, consolidate to better absorb legislation-induced costs, which, to his belief, are born disproportionately by smaller-sized operations. If so, the Dodd-Frank Act imposed on financial institutions in response to the 2008 financial meltdown will only hasten the credit union industry's pace of consolidation in order to further benefit from economies of scale. In essence, a message clearly conveyed by aforementioned studies is that credit union consolidation and growth should be scale economies driven. If so, credit unions should not proceed with internal growth, acquisition, or merger if economies of scale are not expected to emerge.

Most empirical work supports significant, albeit small,

Manuscript received July 19, 2017; revised October 10, 2017. This research was initiated when the author was on sabbatical leave from her institution in spring, 2015.

Su-Jane Chen is with Metropolitan State University of Denver, CO 80217 USA (e-mail: chens@msudenver.edu). economies of scale in virtually all financial institutions but credit unions, where conflicting test results abound. References [1], [3]-[9] support economies of scale. In contrast, [2], [10] document diseconomies of scale. Reference [11] produces mixed findings with respect to various credit union products while [12]-[14] observe no evidence of scale economies. Reference [15] shows that the cost advantage of large credit unions has been increasing over time. Thus, economies of scale may change over time especially in light of the dramatic landscape change endured by the credit union industry, namely steady industry consolidation and concentration.

Given the fact that literature addressing the topic has been mixed and confined to various periods prior to the 2008 financial crisis, the purpose of this research is two-fold. First, it attempts to provide additional evidence on the existence of economies of scale or lack thereof in the credit union industry, using more recent credit union size and performance data. Second, it intends to investigate the nature of the scale economies over time via the use of both pre-2009 and post-2008 data. The rest of the paper is organized as follows. Section II covers data and methodology. Section III presents empirical findings. Section IV concludes this study.

\section{Data AND Methodology}

\section{A. Data}

This study adopts a macro approach, examining credit unions in aggregate. As a result, sample data for this study comprise aggregate data retrieved from quarterly financial performance reports prepared by National Credit Union Administration (NCUA), the federal governing agency of the credit union industry, for the six asset-based size groups of all federally insured credit unions, $\$ 2 \mathrm{M}-, \quad \$ 2 \mathrm{M}-\$ 10 \mathrm{M}$, \$10M-\$50M, \$50M-\$100M, \$100M-\$500M, and \$500M+, respectively, over period 2003-2014.

Credit unions, along with their financial services counterparts, have faced a deteriorating operating environment in the post-2008 era dictated by unfavorable monetary policies and burdening compliance and regulatory requirements. The central bank has adopted aggressive monetary policies to stimulate the economy. Consequently, both short-term and long-term rates have reached historically low levels, reducing spread and putting downward pressure on the financial services sector's earnings. Dodd-Frank Act, enacted in the aftermath of the financial crisis, has limited several major sources of the sector's fee income, such as debit card interchange fees, and imposed additional regulatory compliance costs, further squeezing the sector's bottom line. To better cope with the adverse factors and absorb the ensuing costs, most of which are fixed-natured, 
credit unions may resort to the quick process of external growth from mergers and acquisitions as opposed to the slow process of internal growth over time from accumulated capital. If so, the industry's ongoing consolidation and concentration shall expedite, a notion supported by Tables I and II presented next.

TABLE I: CREDIT UNION NUMBER By ASSET-BASED SIZE GROUP OVER TIME

\begin{tabular}{|c|c|c|c|c|c|c|c|}
\hline & & \multicolumn{3}{|c|}{ Number of Credit Unions } & \multicolumn{3}{c|}{ Credit Union Number Change (\%) } \\
\hline Group & Asset Size & $2003 \mathrm{Q} 1$ & $2008 \mathrm{Q} 4$ & $2014 \mathrm{Q} 4$ & $2003 \mathrm{Q} 1$ & $2008 \mathrm{Q} 4$ & $2014 \mathrm{Q} 4$ \\
\hline 1 & $\$ 2 \mathrm{M}-$ & 1684 & 1197 & 645 & -61.70 & -28.92 & -46.12 \\
\hline 2 & $\$ 2 \mathrm{M}-\$ 10 \mathrm{M}$ & 2752 & 2077 & 1342 & -51.24 & -24.53 & -35.39 \\
\hline 3 & $\$ 10 \mathrm{M}-\$ 50 \mathrm{M}$ & 2910 & 2494 & 2063 & -29.11 & -14.30 & -17.28 \\
\hline 4 & $\$ 50 \mathrm{M}-\$ 100 \mathrm{M}$ & 790 & 755 & 734 & -7.09 & -4.43 & -2.78 \\
\hline 5 & $\$ 100 \mathrm{M}-\$ 500 \mathrm{M}$ & 903 & 954 & 1039 & 4.65 & 8.91 \\
\hline 6 & $\$ 500 \mathrm{M}+$ & 239 & 329 & 450 & 88.28 & 37.66 & 36.78 \\
\hline & & 9278 & 7806 & 6273 & -32.39 & -15.87 & -19.64 \\
\hline
\end{tabular}

TABLE II: CREDIT UNION ASSET DECOMPOSITION BY ASSET-BASED SIZE GROUP OVER TIME

\begin{tabular}{|c|c|c|c|c|c|c|c|}
\hline & & \multicolumn{3}{|c|}{ Credit Union Assets Amount } & \multicolumn{3}{c|}{ Credit Union Assets Presence (\%) } \\
\hline Group & Asset Size & $2003 \mathrm{Q} 1$ & $2008 \mathrm{Q} 4$ & $2014 \mathrm{Q} 4$ & $2003 \mathrm{Q} 1$ & $2008 \mathrm{Q} 4$ & $2014 \mathrm{Q} 4$ \\
\hline 1 & $\$ 2 \mathrm{M}$ & $\$ 1.49 \mathrm{~B}$ & $\$ 0.92 \mathrm{~B}$ & $\$ 0.58 \mathrm{~B}$ & 0.26 & 0.11 & 0.05 \\
\hline 2 & $\$ 2 \mathrm{M}-\$ 10 \mathrm{M}$ & $\$ 14.42 \mathrm{~B}$ & $\$ 10 \mathrm{~B}$ & $\$ 7.52 \mathrm{~B}$ & 2.48 & 1.24 & 0.67 \\
\hline 3 & $\$ 10 \mathrm{M}-\$ 50 \mathrm{M}$ & $\$ 65.55 \mathrm{~B}$ & $\$ 54.74 \mathrm{~B}$ & $\$ 51.01 \mathrm{~B}$ & 11.26 & 6.81 & 4.55 \\
\hline 4 & $\$ 50 \mathrm{M}-\$ 100 \mathrm{M}$ & $\$ 52.26 \mathrm{~B}$ & $\$ 48.06 \mathrm{~B}$ & $\$ 52.49 \mathrm{~B}$ & 8.98 & 5.98 & 4.68 \\
\hline 5 & $\$ 100 \mathrm{M}-\$ 500 \mathrm{M}$ & $\$ 178.18 \mathrm{~B}$ & $\$ 199.80 \mathrm{~B}$ & $\$ 229.68 \mathrm{~B}$ & 30.61 & 24.87 & 20.47 \\
\hline 6 & $\$ 500 \mathrm{M}+$ & $\$ 270.21 \mathrm{~B}$ & $\$ 489.74 \mathrm{~B}$ & $\$ 780.90 \mathrm{~B}$ & 46.42 & 60.97 & 69.59 \\
\hline & & $\$ 582.12 \mathrm{~B}$ & $\$ 803.25 \mathrm{~B}$ & $\$ 1,122.17 \mathrm{~B}$ & 100.00 & 100.00 & 100.00 \\
\hline
\end{tabular}

Table I reports credit union numbers for the six size groups as of 2003 Q1, 2008 Q4, and 2014 Q4, respectively. As depicted in the table, small credit unions with total assets under $\$ 50 \mathrm{M}$ have disappeared drastically during the study period. The smaller is the size, the higher is the percentage decline as exhibited in their respective decrease rates of $61.70 \%, 51.24 \%$, and $29.11 \%$. The dwindling for the bottom-half size tiers has accelerated over time as illustrated by the higher percentage drops in the post-2008 period than in the pre-2009 period, $46.12 \%$ vs. $28.92 \%, 35.39 \%$ vs. $24.53 \%$, and $17.28 \%$ vs. $14.30 \%$, respectively. In contrast, the largest size group, with total assets over $\$ 500 \mathrm{M}$, has vastly expanded, growing at a whopping $88.26 \%$ rate over period 2003-2014. The second largest size group is the only other one that has gained on number of peers, $15.06 \%$, during the same time period.

Table II lists respective asset breakdowns among the six size groups for the same three quarters covered in Table I. As revealed in the table, the larger is the size of the group, the more commanding is its presence in the industry. As a matter of fact, the table clearly shows that the industry's concentration has intensified over time along with its consolidation. All size groups except the largest one have seen their assets shrinking steadily over time. As of the end of 2014 , the bottom two size groups with assets of $\$ 10 \mathrm{M}$ or less account for barely $1 \%$ of the industry's assets, despite the fact that they jointly represent $31.68 \%$ of credit unions. In contrast, the largest size group has captured $69.59 \%$ of the industry's total assets of $\$ 1,122.17$ billion by the end of 2014 , ballooning from $46.42 \%$ as of 2003 Q1 and $60.97 \%$ at 2008 yearend even though it only consists of $7.17 \%$ of all federally insured credit unions of the nation.

\section{B. Methodology}

To investigate economies of scale, the study adopts total assets as the proxy for size. Following [3], [12], [14], the research uses two ratios, operating expenses to total assets and operating expenses to operating income, to measure operational efficiency. The lower the ratios are, the more efficient the operation is. For each size group, the respective means of the two ratios over the entire study period and the two subsample periods (pre 2009 and post 2008) are first calculated. Based on [3], [7], paired $t$ tests are then employed to detect scale economies or lack thereof. To be more specific, the six size groups are paired with one another, yielding 15 size group comparisons for each sample period. The mean difference for an efficiency ratio between each paired set of groups is then tested for statistical significance. Under the null hypothesis, the mean difference is equal to zero. Rejection of the null hypothesis supports economies of scale or diseconomies of scale, pending the sign of the mean difference, in credit union operational efficiency.

\section{EMPIRICAL RESULTS}

Table III contains the paired $t$ test results generated from mean differences in the first efficiency measure employed in this research, operating expenses/total assets, for the 15 size group comparisons over the three time periods, the entire sample period, the pre-2009 period, and the post-2008 period, respectively. The table shows that the majority of the mean differences carries a positive sign and is statistically significant at the $10 \%$ level. Only six out of the 45 paired mean differences reported are associated with a negative sign and only one of them is statistically significant at the $10 \%$ level. Thus, evidence presented in the table supports the existence of economies of scale. The smaller-sized institutions in general have the larger ratios and thus are less efficient. The smallest size group operates at a statistically higher cost per dollar of assets invested than all the other five size groups in the post-2008 era, deteriorating from the pre-2009 era when its operating costs as a percentage of total assets were only distinguishingly higher than those of the top two size groups. In contrast, the largest size group operates more efficiently than the rest, outperforming persistently over all three study periods with an across-the-board $P$-value of .0000 .

Table IV covers the corresponding paired $t$ test results for 
the other efficiency measure used in this study, operating expenses/operating income. While Table III provides supporting evidence for economies of scale, Table IV overwhelmingly validates the existence of scale economies in credit unions. All 45 mean differences are statistically positive at the $10 \%$ significance level with the majority of them significant at the $0.1 \%$ level as illustrated by the $P$-values. In all comparisons, the smaller the size group is, the higher the operating costs are incurred to generate each dollar of operating income. The table also signifies a widening efficiency gap between small and large credit unions since the mean difference for the ratio increases as the size difference for the matched pair enlarges. Moreover, the table shows that small credit unions have fallen further behind their large peers over time in their operational efficiency, as disclosed by the growing mean difference over the two subsample periods for each paired comparison. That is, economies of scale have become more pronounced in the post-2008 era than in the pre-2009 era.

TABLE III: TEST RESUlTS OF PAIRED DIFFERENCES IN OPERATING EXPENSES/TOTAL ASSETS

\begin{tabular}{|c|c|c|c|c|c|c|}
\hline \multirow{2}{*}{ Paired credit union groups } & \multicolumn{2}{|c|}{$2003-2014$} & \multicolumn{2}{|c|}{$2003-2008$} & \multicolumn{2}{|c|}{$\begin{array}{c}\text { Mean } \\
\text { difference }\end{array}$} \\
\cline { 2 - 6 } & Mean difference & $P$-value & Mean difference & & $0.009-2014$ \\
\hline 1 with 2 & 0.0013 & 0.0809 & 0.0005 & 0.2560 & 0.0020 \\
\hline 1 with 3 & 0.0017 & 0.0271 & 0.0000 & 0.4745 & 0.0033 & 0.0177 \\
\hline 1 with 4 & 0.0012 & 0.0633 & -0.0005 & 0.2216 & 0.0029 & 0.0207 \\
\hline 1 with 5 & 0.0032 & 0.0000 & 0.0019 & 0.0012 & 0.0045 \\
\hline 1 with 6 & 0.0120 & 0.0000 & 0.0109 & 0.0000 & 0.0131 & 0.0004 \\
\hline 2 with 3 & 0.0004 & 0.3295 & -0.0004 & 0.2658 & 0.0013 & 0.2343 \\
\hline 2 with 4 & 0.0000 & 0.4889 & -0.0009 & 0.0825 & 0.0009 & 0.2913 \\
\hline 2 with 5 & 0.0019 & 0.0103 & 0.0015 & 0.0172 & 0.0024 & 0.0542 \\
\hline 2 with 6 & 0.0107 & 0.0000 & 0.0105 & 0.0000 & 0.0110 & 0.0000 \\
\hline 3 with 4 & -0.0004 & 0.3031 & -0.0005 & 0.1884 & -0.0004 & 0.4110 \\
\hline 3 with 5 & 0.0015 & 0.0271 & 0.0019 & 0.0008 & 0.0012 & 0.2138 \\
\hline 3 with 6 & 0.0103 & 0.0000 & 0.0109 & 0.0000 & 0.0097 & 0.0000 \\
\hline 4 with 5 & 0.0020 & 0.0039 & 0.0024 & 0.0000 & 0.0015 & 0.1295 \\
\hline 4 with 6 & 0.0108 & 0.0000 & 0.0114 & 0.0000 & 0.0101 & 0.0000 \\
\hline 5 with 6 & 0.0088 & 0.0000 & 0.0090 & 0.0000 & 0.0086 & 0.0000 \\
\hline
\end{tabular}

Asset Size: Group 1 = under $\$ 2 \mathrm{M}$; Group 2 = \$2M-10M; Group 3 = \$10M-\$50M; Group 4 = \$50M-\$100M; Group 5 = \$100M-\$500M; Group $6=$ over $\$ 500 \mathrm{M}$

TABLE IV: TEST RESULTS OF PAIRED DIFFERENCES IN OPERATING EXPENSES/GROSS INCOME

\begin{tabular}{|c|c|c|c|c|c|c|}
\hline \multirow[b]{2}{*}{ Paired credit union groups } & \multicolumn{2}{|c|}{ 2003-2014 } & \multicolumn{2}{|c|}{$2003-2008$} & \multicolumn{2}{|c|}{$2009-2014$} \\
\hline & Mean difference & $P$-value & Mean difference & $P$-value & $\begin{array}{c}\text { Mean } \\
\text { difference }\end{array}$ & $P$-value \\
\hline 1 with 2 & 0.0561 & 0.0147 & 0.0332 & 0.0000 & 0.0790 & 0.0000 \\
\hline 1 with 3 & 0.0857 & 0.0003 & 0.0473 & 0.0000 & 0.1241 & 0.0000 \\
\hline 1 with 4 & 0.1135 & 0.0000 & 0.0620 & 0.0000 & 0.1650 & 0.0000 \\
\hline 1 with 5 & 0.1585 & 0.0000 & 0.1030 & 0.0000 & 0.2140 & 0.0000 \\
\hline 1 with 6 & 0.2814 & 0.0000 & 0.2141 & 0.0000 & 0.3487 & 0.0000 \\
\hline 2 with 3 & 0.0296 & 0.0896 & 0.0142 & 0.0142 & 0.0450 & 0.0078 \\
\hline 2 with 4 & 0.0574 & 0.0033 & 0.0289 & 0.0000 & 0.0860 & 0.0000 \\
\hline 2 with 5 & 0.1024 & 0.0000 & 0.0699 & 0.0000 & 0.1350 & 0.0000 \\
\hline 2 with 6 & 0.2253 & 0.0000 & 0.1809 & 0.0000 & 0.2697 & 0.0000 \\
\hline 3 with 4 & 0.0278 & 0.0742 & 0.0147 & 0.0170 & 0.0409 & 0.0102 \\
\hline 3 with 5 & 0.0728 & 0.0001 & 0.0557 & 0.0000 & 0.0899 & 0.0000 \\
\hline 3 with 6 & 0.1957 & 0.0000 & 0.1668 & 0.0000 & 0.2247 & 0.0000 \\
\hline 4 with 5 & 0.0450 & 0.0052 & 0.0410 & 0.0000 & 0.0490 & 0.0017 \\
\hline 4 with 6 & 0.1679 & 0.0000 & 0.1521 & 0.0000 & 0.1837 & 0.0000 \\
\hline 5 with 6 & 0.1229 & 0.0000 & 0.1111 & 0.0000 & 0.1347 & 0.0000 \\
\hline
\end{tabular}

Asset Size: Group 1 = under $\$ 2 \mathrm{M}$; Group 2 = \$2M-10M; Group 3 = \$10M-\$50M; Group 4 = \$50M-\$100M; Group 5 = \$100M-\$500M;

Group $6=$ over $\$ 500 \mathrm{M}$

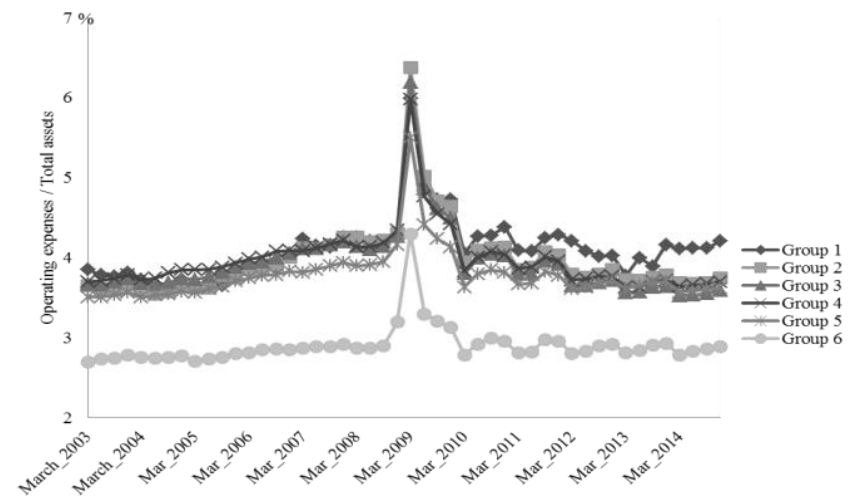

Fig. 1. Operating expenses/total assets (by asset-based size group).

Economies of scale depicted in Tables III and IV are supported by evidence illuminated in Figs. 1 and 2. Fig. 1 presents operating expenses as a percentage of total assets for the six asset-size groups over period 2003-2014. As illustrated, the ratio suffered shock-induced across-the-board peaks immediately following the 2008 Great Recession. Nevertheless, the figure demonstrates the largest size group's far superior operational efficiency. It also reveals that the efficiency divergence between the smallest size group and the five larger groups has increased post the 2008 financial crisis. The widening deterioration is particularly noticeable over the recent past.

Fig. 2 displays operating expenses as a percentage of operating income for the six size groups over period 2003-2014. It shows that the ratio for all six groups rose sharply during the darkest days of the financial crisis. Nonetheless, the figure provides overwhelming evidence in 
support of economies of scale. Persistently portrayed in the figure, the larger the size group is, the lower the operating costs it incurs in relation to operating income and thus the more efficient the group is. It also shows that the efficiency has worsened for all six size groups in the post-Great Recession era.

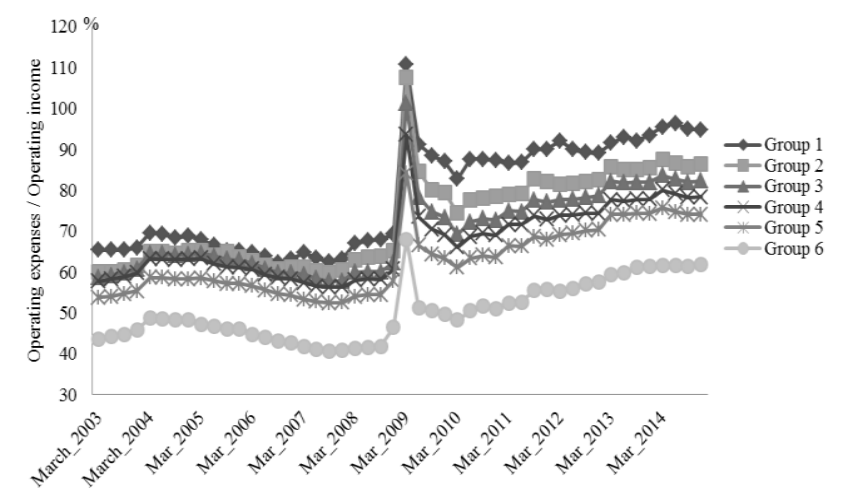

Fig. 2. Operating expenses/operating income (by asset-based size group).

The deteriorating operating environment noted earlier in the paper in the post-2008 period has clearly caused the operating costs per unit of operating income to rise for all credit unions. However, the pain is not uniformly borne among the six size groups. The smaller the group size is, the bigger the ratio increase is and the less efficient its operation has become, widening the efficiency gap between large and small size groups. The trend is particularly worrisome for the smallest size group. Its operating costs per dollar of operating income hover around 95\%-mid 96\% in 2014, leaving hardly any room for error, let alone growth. Not surprisingly, then, more than $46 \%$ of the credit unions in this group have disappeared since the end of 2008. At this declining rate, the entire group may cease to exist in the near future. This asymmetric cost structure most likely has contributed to the industry's acceleration in consolidation and concentration as documented earlier, respectively, in Tables I and II. Faced with increasing operating costs in the post-2008 period, credit unions, in hopes of benefitting from economies of scale, have resorted to mergers and acquisitions for quick, external growth.

\section{CONCLUSIONS}

Test results derived from conducting statistical analysis on credit union data in aggregate overwhelmingly support the existence of economies of scale. Given the fact that many small credit unions are heavily subsidized by their sponsoring organizations, the well-documented scale economies are most likely understated. Empirical evidence further shows that scale economies have expanded over time in line with the industry's consolidation and concentration. Thus, the steady consolidation and concentration observed in the credit union industry will continue to pick up speed. As a result, small credit unions will remain an endangered species, disappearing at a faster rate than ever. In contrast, large credit unions will continue to mushroom and expand to reap the fruit of economies of scale, furthering its operational efficiency. These findings have significant implications to credit union stakeholders.
First, the existence of economies of scale provides welcome relief to credit union members since scale economies help mitigating potential conflicts of interest between current and new members as credit unions grow. Second, credit union policy makers and regulators, in light of the findings, may consider easing legal restrictions on credit union membership and permissible products to further promote growth. However, the growth orientation strikes at the heart of the credit union movement since small credit unions (those with assets under $\$ 50 \mathrm{M}$ or those in the bottom three size tiers) are the essence of the movement but are shrinking fast. This is not an issue to be taken lightly. After all, these small credit unions as of the end of 2014 represent roughly $65 \%$ of all credit unions in the industry despite the fact that they jointly own less than $5.5 \%$ of the industry's assets. To preserve the credit union cooperative nature and profile, the government may consider lightening up the compliance costs for small credit unions by exempting them from many of the burdensome laws enacted after the 2008 financial crisis and designed to rein in billion-dollar financial institutions. Board directors and management of credit unions, the small ones in particular, should actively seek out opportunities to collaborate with their peers such as exploring the formation of credit union service organizations to share resources and to split costs.

This study makes important contributions. First, it provides additional, significant empirical evidence in support of economies of scale. Second, it updates the literature by using most recent data, notably post-2008 data. Third, it shows that scale economies increase over time, lending justification for the credit union industry's acceleration in consolidation.

\section{REFERENCES}

[1] R. Taylor, "Economies of scale in large credit unions," Applied Economics, vol. 4, no. 1, pp. 33-40, March 1972.

[2] R. S. Koot, "On economies of scale in credit unions," Journal of Finance, vol. 33, no. 4, pp. 1087-1094, September 1978.

[3] T. Kohers and D. Mullis, "An update on economies of scale in credit unions," Applied Economics, vol. 20, no. 12, pp. 1653-1659, December 1988.

[4] J. A. Wilcox, "Economies of scale and continuing consolidation of credit unions," Federal Reserve Bank of San Francisco Economic Letter, pp. 2005-29, November 4, 2005.

[5] J. D. Wolken and F. J. Navratil, "Economies of scale in credit unions: Further evidence," Journal of Finance, vol. 35, no. 3, pp. 769-77, June 1980.

[6] J. D. Murray and R. W. White, "Economies of scale and economies of scope in multiproduct financial institutions: A study of British Columbia credit unions," Journal of Finance, vol. 38, no. 3, pp. 887-902, June 1983.

[7] D. McKillop, C. Ferguson, and D. Nesbitt, "Paired difference analysis of size economies in UK credit unions," Applied Economics, vol. 27, no. 6 , pp. 529-537, 1995.

[8] H. M. Sollenberger and A. W. Stanecki, "Credit union financial performance: The impact of asset size," Bank Accounting and Finance, pp. 3-14, April-May 2009.

[9] D. C. Wheelock and P. W. Wilson, "Are credit unions too small?" The Review of Economics and Statistics, vol. 93, no. 4, pp. 1343-1359, November 2011.

[10] M. J. Flannery, "An economic evaluation of credit unions in the United States," Federal Reserve Bank of Boston Research Report, no. 54, 1974.

[11] H. Y. Kim, "Economies of scale and economies of scope in multiproduct financial institutions: further evidence from credit unions," Journal of Money, Credit, and Banking, vol. 18, no. 2, pp. 220-226, May 1986.

[12] W. N. Cox and P. V. Whigham, "What distinguishes larger and more efficient credit unions?" Economic Review, Federal Reserve Bank of Atlanta, pp. 34-41, October 1984. 
[13] H. O. K. Fried, C. A. Lovell, and P. Von Eeckaut, "Evaluating the performance of US credit unions," Journal of Banking and Finance, vol. 17, no. 2-3, pp. 251-265, April 1993.

[14] A. Sibbald and L. McAlevey, "Examination of economies of scale in credit unions: a New Zealand study," Applied Economics, vol. 35, no. 11 , pp. 1255-1264, 2003.

[15] J. A. Wilcox, "Performance divergence of large and small credit unions," Federal Reserve Bank of San Francisco Economic Letter, pp. 2006-19, August 4, 2006.
Su-Jane Chen holds a Ph.D. degree in finance from University of Missouri-Columbia, USA. She is a professor at and former chair of Department of Finance, Metropolitan State University of Denver. Her research interests in behavioral finance, capital budgeting, credit union industry, international finance, IPOs, REITs, and security pricing have led to numerous publications in refereed finance and economics journals, including Journal of Banking and Finance, Journal of Financial Research, and Real Estate Economics. She has served on a Colorado Credit Union's board of directors since 2002 